\title{
Job Satisfaction to Enhance Leadership Style of The Principal
}

\author{
Sutji Harijanto \\ Pakuan University, Indonesia \\ E-mail: sutjihar@unpak.ac.id
}

\begin{abstract}
This study aims to explore job satisfaction enhances the leadership style of the principal. This study uses a survey which obtained 60 samples from an affordable population of 146 senior high school headmaster by taking them through simple random sampling. The result shows that teacher's job satisfactions strengthened the higher score of the leadership style of the principal. Finally, a teacher's job satisfaction for teaching practices were examined at one point in time. The quality of leadership style of the principal will increase.
\end{abstract}

Keywords: learning system, learning paradigm, teacher professionalism

\section{INTRODUCTION}

The quality of the school is various levels of start primary school to high school and vocational school facing variety various obstacles, obstacles and problems especially in the field of good educational duties as well as administrative ones getting the spotlight is about education management, education quality, the quality of teachers and the quality of principals. Improved management education and teacher quality improvement depends heavily on the quality of a head school in charge of managers.

The above facts are an indication of the importance of the principal as a manager. The inability of the school principal to manage can lead to low student input, low quality of teaching and learning process, low teacher qualification, low work motivation, work climate, principal leadership style is not appropriate to influence subordinates, organizations that are applied by the citizens of the school and others. If this is not addressed, it can create distortions that will hamper the process of educational development and the difficulty of competing in national and international forums.

The goal of this study is to analyze the influence of principal leadership behavior and teacher's job satisfaction on school quality. Ngalim Purwanto (2008: 45) said that to create an ideal atmosphere in the management of education in schools to be achieved in accordance with the vision, mission of the school, needed an adequate school leaders who can adjust to their own school environment by knowing various styles of leadership, expected education leaders, especially principals, can choose and apply which leadership. behaviors are viewed more effectively based on the characteristics, group behavior and the conditions and situation of the institutions they lead.

\section{Methodology}

This study was conducted with the aim to obtain data, information and facts that are valid and reliable about the influence of leadership style on high school head job satisfaction.

This research uses survey method with causal approach. In the causal approach is used technical analysis of path analysis data (path analysis). This study will examine or analyze the interrelationship between research variables, and measure the influence of one variable on other variables. The variables studied are two types, namely: (1) Leadership Style (X) and (2) Job Satisfaction (Y).

The target population in this study is all senior high school principals in East Jakarta. The affordable population in this study were 146 heads of public and private high schools in East Jakarta. The sampling technique used is Simple Random Sampling is a simple random sampling. Using this technique obtained 60 samples from an affordable population of 146 . 
Data collection techniques were conducted using questionnaires given and answered by the headmaster of SMA. Special principal performance questionnaires were assessed by East Jakarta DikudinDikmen, Kasi SMA, and SMA Supervisory Coordinator. Assessment is done by rating scale, to assess the principal.

\section{RESULTS AND DISCUSSION}

\section{The Influence of Leadership Style (X) on Job Satisfaction (Y).}

Description of the data shows that the normality test of Leadership Style (X) is above 0.05 then the data distribution is stated to meet the assumption of normality. Then $0.957>0.05$ denotes the normal distribution. Meanwhile, Job Satisfaction (Y)shows a value above 0.05 then the data distribution is stated to meet the assumption of normality. Then $0.889>0.05$ denotes the normal distribution.

The value of $\mathrm{R}$ which is the symbol of the correlation coefficient value. In the above example the correlation value is 0.767 . This value can be interpreted that the relationship between the two research variables is in strong category. Through this table also obtained the value of $\mathrm{R}$ Square or coefficient of determination (KD $=\mathrm{R}$ square $\mathrm{x} 100 \%$ ) which shows how good the regression model formed by the interaction of independent variables and dependent variables. The value of $\mathrm{KD}$ obtained is $58.8 \%$ which can be interpreted that the independent variable $\mathrm{X}$ has a contribution influence of $58.8 \%$ to variable $\mathrm{Y}$ and $41.2 \%$ other influenced by other factors outside the variable $\mathrm{X}$.

ANOVA $^{\text {a }}$
\begin{tabular}{|l|l|l|l|l|l|}
\hline Model & $\begin{array}{l}\text { Sum of } \\
\text { Squares }\end{array}$ & df & $\begin{array}{l}\text { Mean } \\
\text { Squar } \\
\text { e }\end{array}$ & F & Sig. \\
\hline Regression & 3615.600 & 1 & $\begin{array}{l}3615 . \\
600\end{array}$ & $\begin{array}{l}82.7 \\
32\end{array}$ & $\begin{array}{l}.00 \\
0^{\mathrm{b}}\end{array}$ \\
Residual & 2534.734 & 58 & $\begin{array}{l}43.70 \\
2\end{array}$ & & \\
Total & 6150.333 & 59 & & \\
\hline
\end{tabular}
a. Dependent Variable: Leadership Style (X)
b. Predictors: (Constant) : Job Satisfaction (Y)

The table of Anova is used to determine the level of significance or linearity of the regression. The criterion can be determined based on the F test or the Significance value test (Sig.). The most convenient way with the Sig test, provided that, if the Sig Value. $<0.05$, then the regression model is linear, and vice versa. Based on the third table, we get the Sig value. $=0,000$ which means < significant criterion (0.05), thus the regression equation model based on research data is significant meaning, linear regression model meets the linearity criteria.

The model of regression equation obtained with the coefficient of constant and coefficient of variable in Unstandardized Coefficients column B. Based on this table obtained model of regression equation: $\mathrm{Y}=$ $31,770+0,739 \times 1$.

The value of Pearson's $r$ of 0.767 with Sig. (2-tailed) of $0.000<0.05$ so it was decided that job satisfaction and leadership style were significantly and significantly related.

\section{Direct and Indirect Influence}

The style of leadership directly affects job satisfaction. The great coefficient between leadership style to job satisfaction is $r=0.767$. Great influence of leadership style on job satisfaction is $58.8 \%$. These results indicate that the influence of leadership style can provide individual job satisfaction. These findings support the performances of Colquit, LePine, and Wesson (2009: 37) that a good leadership style will be able to provide job satisfaction for a person. With the style of leadership creates an atmosphere of intimate relationships so that subordinates and superiors occur a good understanding, good cooperation, so that the work or task of the organization can run smoothly without significant obstacles, so that organizational goals are achieved according to predetermined plans and ultimately provide job satisfaction because goals are well achieved.

These results indicate that the influence of leadership style can improve individual job satisfaction. With a leadership style to create an atmosphere of intimate relationships between subordinates and superiors can do a good cooperation, thus raising awareness to do the job or task as well as possible to achieve the expected goals. If the work can be done well, this shows the better job satisfaction.

\section{CONCLUSION}

Based on the analysis of the research results can be submitted as follows:

Leadership style directly affects teacher's job satisfaction of $58.8 \%$. So Style of Leadership proved direct influence on Job Satisfaction. In other words, the more optimal the Leadership Style of the principal and the higher Job Satisfaction of teachers

\section{Implications for Leadership Style}

Need to optimize the function of leadership, including the leadership style of the principal to build comfortable coordination with colleagues or subordinates to be effective and in sync with the desires of subordinates in achieving organizational goals. This is understandable considering the head of the school's authorization holders in policymakers, 
which is important to build subordinate motivation, so as to increase job satisfaction as an encouragement in increasing work commitment to achieve better school performance.

Implications for Job Satisfaction

Need to cultivate awareness within each subordinate (teachers and school administrators) that job satisfaction can motivate employee performance. Job satisfaction can encourage every personnel to always try to find strategies to improve performance, such as being active in contributing to the school. This can be instilled at regular meetings.

It is necessary to create the conditions of the principal's office, teachers, administrators and classrooms physically and psychologically comfortable. Convenience of work is a physiological need (physiological Needs-Maslow) that can contribute to job satisfaction. The required facilities and infrastructure at least meet the standard of facilities and infrastructure as stipulated by the National Education Standards Agency (BSNP).

Need to cultivate the attitude of care and support of colleagues both personal and work group. Thus the working system in totality that fosters happy working situation can support the achievement of optimal work productivity and give employee job satisfaction. It is necessary to update a system of rewards and performance-based sanctions that are fairly enforceable in each school. Because it is an element: appreciate the work of others, provide the appropriate rewards as well as a driver of employee job satisfaction.

\section{REFERENCES}

AnoragaPandji, PsikologiKerja. Jakarta: Rineka Cipta,2001.

Dole, Carol and Schroeder, Richard G., The Impact of Varios Factors on the Personality, Job Satisfaction and Turn Over Intentions of ProfesionaL. Auditing Journal, 2001.

George, Jennifer M. dan Gareth R. Jones, Understanding and Managing Organizational Behavior. New Jersey: Upper Saddle River, 2002.

Kreitner Robert dan Angelo Kinicki, Organizational Behavior (Arizona State University: Richard D. Irwin, Inc. 2000. Organizational Behavior. New York: McGraw-Hill. 2008.

Kreitner and Kinichi, Organization Theory and The New Public Administration Boston Allyn and Bacon, Inc.. 2003.
Luthans, Fred. Organizational Behavior, New York: McGraw-Hill, Inc., 1995.

Matondang M.H., Kepemimpinan, BudayaOrganisasidanManajemenStrategik. Yogyakarta :Grahallmu, 2008.

Ngalim.Purwanto (2008).AdministrasidanSupervisiPendidikan, Bandung: PT RemajaRosdakarya

Noe, Raymond A. ef at.Human Resources Management, Boston: McGraw-Hill, 2000.

RivaiVeithzal, KepemimpinandanPerilakuOrganisasi. Jakarta : PT Raja GrafindoPersada, 2003. Performance Appraisal. Jakarta: GrafindoPersada, 2005.

Robbins, Stephen P. TeoriOrganisasi, Struktur, DesaindanAplikasi. Terjemahan Yusuf Udaya. Edisi 3. Jakarta: PenerbitArcan, 1994.

Robbins, Stephen P dan Mary Coulter.Manajemen, Jilid 2. Terjemahan Harry Slamet\&Ernawati Lestari. Jakarta: PT. Indeks, 2007.

Robbins, Stephen P. dan Timothy A. Judge, Organizational Behavior. New Jersey: McGraw-Hill, 2007.

RukyAchmad S., Performance Management System. Jakarta : PT Gramedia PustakaUtama, 2006.

Salusu, J. PengambilanKeputusanStrategik.Jakarta: GramediaWkJiasarana Indonesia, 2003.

Sopiah, PerilakuOrganisasi. Yogyakarta: C.V AndiOfset, 2008.

Stoner, James F. dan Edward E. Freeman, Manajemen, Fifth Edition, Terjemahan W. Bakowatun. Jakarta: Intermedia, 1994.

ThohaMiftah, PerilakuOrganisasi. Jakarta: PT Raja GrafindoPersada, 2001.

Tyson Shaumdan Tony Jacson .The Essence of Organizational Behavior .TerjemahkanolehDedyJacobus . Yogyakarta: Andi, 2000.

Weihrich, Heinz dan Harold Koonz.Management : A global Perspective. Philippines: McGraw-Hill, 2005.

Yukl, Gary. Leadership In Organizations, New Jersey: Prentice Hall., 2002.

Wexley Kenneth N. and Gary A. Yukl, Organisasi Behavior and Personnel Psychology. USA: Ricard D. Irwin, Inc., 1984.

PerilakuOrganisasidanPsikologiPersonalia, TerjemahanMuh.Shobaruddin.Jakarta : PT. RinekeCipta, 2005 